\title{
PERAN PARTISIPASI MASYARAKAT DALAM MENINGKATKAN MUTU PENDIDIKAN MADRASAH (STUDI KASUS DI MADRASAH IBTIDAIYAH ISLAHUL MUTA'ALLIM PAGUTAN KOTA MATARAM)
}

\author{
Fathul Maujud \\ UIN Mataram \\ fathulmaujud@yahoo.com
}

\begin{abstract}
Abstrak: Masyarakat memiliki peran yang strategis dalam upaya meningkatkan mutu pendidikan di madrasah, upaya tersebut diimplementasikan melalui partisipasi dan keterlibatan mereka baik secara moril maupun materil. Peran partisipasi masyarakat dalam meningkatkan mutu pendidikan di madrasah dapat berupa peran sebagai perencana dan pengawas program yang sudah disusun oleh madrasah. Partisipasi masyarakat merupakan salah satu bagian penting bagi peningkatan mutu pendidikan madrasah. Partisipasi menuntut adanya pemahaman yang sama dari pihak madrasah dan masyarakat (orangtua) terhadap visi, misi, dan tujuan pendidikan di madrasah. Partisipasi tidak cukup hanya dipahami oleh madrasah sebagai bagian yang penting bagi keberhasilan peningkatan mutu pendidikan, akan tetapi masyarakat juga harus meningkatkan keterlibatan mereka serta memahami makna pentingnya partisipasi bagi pembangunan madrasah. Penelitian ini bertujuan untuk mendeskripsikan dan menganalisis: 1) Bentuk partisipasi masyarakat dalam meningkatkan mutu pendidikan di Madrasah Ibtidaiyah Islahul Muta'allim Pagutan Kota Mataram. 2) Peran partisipasi masyarakat dalam meningkatkan mutu pendidikan di Madrasah Ibtidaiyah Islahul Muta'allim Pagutan Kota Mataram. 3) Hambatan yang dihadapi oleh masyarakat dalam berpartisipasi untuk meningkatkan mutu pendidikan di Madrasah Ibtidaiyah Islahul Muta'allim Pagutan Kota Mataram. Penelitian dilakukan di Madrasah Ibtidaiyah Islahul Muta'allim Pagutan kota Mataram dengan menggunakan pendekatan kualitatif, teknik pengumpulan data yang dipergunakan adalah observasi partisipan, wawancara mendalam, dan dokumentasi. Data dalam penelitian ini dianalisis dengan menggunakan teknik analisis interaktif yang dikembangkan oleh Miles dan Huberman. Sedangkan pengecekan keabsahan data dilakukan dengan uji kepercayaan (credibility), keteralihan (transferability), kebergantungan (dependability) reliabilitas, dan objektifitas (confirmability). Hasil penelitian ini yaitu: (1) Bentuk partisipasi masyarakat dalam upaya meningkatkan mutu pendidikan di madrasah dikelompokkan menjadi tiga bagian yaitu input, proses, dan output. (2) Peran partisipasi masyarakat dalam meningkatkan muru pendidikan dibagi ke dalam peran perencana dan pengawas. (3) Hambatan yang dihadapi masyarakat adalah masalah kesibukan dalam bekerja, kurangnya informasi tentang program madrasah, dan masih minimnya pengetahuan sebagian besar masyarakat tentang pentingnya arti partisipasi.
\end{abstract}

Kata kunci: Peran, partisipasi masyarakat, mutu pendidikan. 


\section{PENDAHULUAN}

\section{A. Konteks Penelitian}

Desentralisasi merupakan salah satu konsep dalam gagasan dan praktik tentang partisipasi masyarakat. Penyerahan wewenang pengelolaan dan pengembangan madrasah dari pemerintah pusat ke daerah sebagai perwujudan komitmen pemerintah dalam memberdayakan lingkungan masyarakat beserta potensi yang dimilikinya.

Madrasah sebagai suatu lembaga pendidikan tidaklah mungkin berdiri secara sendirian, ada komponen-komponen lain sebagai penyangga berdirinya institusi tersebut, diantaranya adalah masyarakat. Masyarakat dan madrasah seperti disiyalir oleh Pidarta ${ }^{1}$ memiliki hubungan saling memberi dan saling menerima. Lembaga pendidikan merealisasi apa yang dicita-citakan oleh warga masyarakat tentang pengembangan putra-putra mereka. Hampir tidak ada orang tua siswa yang mampu membina sendiri putra-putra mereka untuk dapat tumbuh dan berkembang secara total, integratif dan optimal seperti yang dicitacitakan oleh bangsa Indonesia. Itulah sebabnya lembaga-lembaga pendidikan mengambil alih tugas ini. Lembaga pendidikan memberi sesuatu yang sangat berharga bagi masyarakat.

Melihat jasa dan pemberian dari madrasah kepada masyarakat, maka sebaliknya akan terjadi timbal balik diantara keduanya. Masyarakat juga memberikan sesuatu yang tidak kalah pentingnya yaitu berupa tanggung jawab. Masyarakat yang terbina dengan baik akan merasa bahwa lembaga pendidikan itu adalah juga miliknya, dipelihara, dipertahankan, dan dimajukan secara baik.

Sebuah lembaga pendidikan yang mengadakan kontak dengan masyarakat akan memudahkan organisasi pendidikan tersebut menyesuaikan diri dengan situasi dan kondisi lingkungannya. Lembaga pendidikan lebih mudah menempatkan dirinya dalam masyarakat dalam arti dapat diterima sebagai bagian dari milik masyarakat. Dengan demikian, Hubungan masyarakat atau yang dikenal dengan term "humas" memiliki peran strategis dalam upaya pengembangan mutu lembaga pendidikan. Masyarakat yang dimaksud disini bisa orang tua murid atau masyarakat umum ataupun pihak yang berada di sekitar lingkungan madrasah.

Orientasi pendidikan di era globalisasi mengutamakan mutu sebagai produk pendidikan. Oleh karena itu, lembaga pendidikan yang tidak mengorientasikan pembelajarannya pada pencapaian mutu, cepat atau lambat akan ditinggalkan oleh konsumen atau masyarakatnya. Sebaliknya, lembaga pendidikan yang menjadikan mutu

${ }^{1}$ Made Pidarta, Manajemen Pendidikan Indonesia (Jakarta: Rineka Cipta, 2004), 180. 
sebagai orientasi dan standar kualitasnya akan terus dicari oleh masyarakat sebagai konsumen pendidikan.

Istilah mutu atau kualitas berasal dari bahasa Inggris "quality"2. Sedangkan secara umum, mutu mengandung pengertian suatu derajat atau tingkat keunggulan suatu produk dari hasil kerja baik berupa barang maupun jasa, secara langsung maupun tidak langusng, kongkrit maupun abstrak. Mutu pendidikan menyangkut dapat tidaknya hasil pendidikan dipakai sebagai instrumen yang tepat guna untuk keperluan hidup. Mutu ini menyangkut mengenai silabus, materi pengetahuan, nilai-nilai, hal normatis dan estetis, unsur yang efektif dan ekonomis, keterampilan sosial dan manajerial, keterampilan teknis, standardisasi, tenaga guru, dan lain-lain. Mutu merupakan orientasi utama dari suatu produk, sejauh mana suatu produk memenuhi kriteria, standar atau rujukan.

Dengan demikian, orientasi mutu pendidikan amat terkait dengan tiga hal: (1) In-put, yaitu segala sesuatu yang harus tersedia untuk berlangsungnya proses pendidikan, baik berupa sumberdaya, perangkat lunak maupun harapan-harapan sebagai panduan bagi berlangsungnya proses pendidikan. In-put sumberdaya meliputi SDM (Kepala madrasah, guru, karyawan, siswa, dan masyarakat) dan sumberdaya lainnya (peralatan, perlengkapan, uang, bahan, dan sebagainya). In-put perangkat lunak meliputi struktur organisasi sekolah, peraturan perundang-undangan, deskripsi tugas, rencana, program, dan lain-lain. In-put harapan berupa visi, misi, tujuan dan sasaran-sasaran yang ingin dicapai oleh madrasah. Kesiapan in-put sangat diperlukan agar proses pembelajaran dapat berlangsung dengan baik. (2) Proses. Yakni usaha untuk mengubah sesuatu menjadi sesuatu yang lain yang berpengaruh. Sesuatu yang berpengaruh terhadap berlangsungnya proses disebut in-put, sedang sesuatu dari hasil proses dinamakan out-put. Dalam pendidikan madrasah, proses yang dimaksud adalah proses pengambilan keputusan, pengelolaan lembaga, pengelolaan program, proses belajar mengajar, serta proses monitoring dan evaluasi. Suatu proses dikatakan bermutu tinggi manakala terjadi perpaduan dan koordinasi antara in-put (kepala madrasah, guru, siswa, masyarakat, kurikulum, biaya pendidikan, peralatan dan lain-lain) secara harmonis sehingga mampu menciptakan suasana pembelajaran yang menyenangkan, pembelajaran yang mampu mendorong motivasi dan minat belajar, dan pembelajaran yang mampu memberdayakan peserta didik. Sedangkan proses dikatakan rendah manakala menampakkan hasil sebaliknya. (3) Out-put merupakan hasil kinerja lembaga pendidikan. Kinerja madrasah adalah prestasi yang dihasilkan dari proses pendidikannya.

\footnotetext{
2 John M. Echols dan Hassan Sadilly, Kamus Inggris Indonesia, Jakarta: Gramedia, 2000, 460.
} 
Upaya peningkatan mutu pendidikan madrasah sebagaimana disebutkan di atas bukanlah masalah yang sederhana, tetapi memerlukan penanganan yang multidimensi dengan melibatkan berbagai pihak yang terkait termasuk masyarakat dengan segala macam bentuk partisipasinya. Dalam konteks ini, Madrasah Ibtidaiyah Islahul Muta'allim Pagutan Kota Mataram, merupakan madrasah yang didirikan atas dasar prakarsa dan dukungan seluruh masyarakat di Lingkungan Karang Genteng Pagutan Kota Mataram sebagai wadah bagi putra-putri mereka untuk menuntut ilmu guna turut menunjang terciptanya manusiamanusia pembangunan yang seutuhnya.

Dalam perjalanan kiprahnya, Madrasah Ibtidaiyah ini banyak disupport dan didukung oleh masyarakat, tidak hanya bersifat material tetapi juga bersifat non-material. Masyarakat dengan didorong oleh kesadarannya baik secara kolektif maupun individual, telah ikut berpartisipasi untuk menyokong dan mendukung eksistensi dan keberlanjutan madrasah ini ke depannya. Adalah fakta bahwa dalam setiap tahun ajaran baru madrasah ini memiliki jumlah pendaftar (calon siswa baru) dengan jumlah yang banyak, mengalahi jumlah pendaftar pada Sekolah Dasar Negeri yang secara geografis bersebelahan dengan madrasah ini. Fakta ini mengisyaratkan bahwa masyarakat ikut berpartisipasi untuk keberadaan dan keberlanjutan pendidikan yang terdapat di madrasah tersebut.

Disamping itu, bentuk lainnya dari partisipasi masyarakat adalah keterlibatan mereka dalam komite madrasah, pembangunan fisik madrasah, penyelarasan programprogram pendidikan dan pengajaran di madrasah dan lain sebagainya. Melihat betapa pentingnya partisipasi masyarakat dalam bidang pendidikan, maka perlu ditingkatkan lagi baik kualitas dan intensitasnya, bentuk pelibatan maupun jangkauannya, yang kesemua itu hanya akan terwujud apabila terdapat saling pengertian antara pihak-pihak yang terkait, di antaranya pihak pemerintah, madrasah, orang tua, dan masyarakat.

Melihat pada realitas tersebut, peneliti merasa tertarik untuk melakukan penelitian tentang peran partisipasi masyarakat dalam meningkatkan mutu pendidikan madrasah, penelitian ini mengambil suatu studi kasus tentang peran partisipasi masyarakat dalam meningkatkan mutu pendidikan madrasah di Madrasah Ibtidaiyah Islahul Muta'allim Pagutan Kota Mataram.

\section{B. Fokus Penelitian}

1. Apa bentuk partisipasi masyarakat dalam meningkatkan mutu pendidikan di Madrasah Ibtidaiyah Islahul Muta'allim Pagutan Kota Mataram? 
2. Bagaimana peran partisipasi masyarakat dalam meningkatkan mutu pendidikan di Madrasah Ibtidaiyah Islahul Muta'allim Pagutan Kota Mataram?

3. Apa hambatan masyarakat dalam berpartisipasi untuk meningkatkan mutu pendidikan di Madrasah Ibtidaiyah Islahul Muta'allim Pagutan Kota Mataram?

\section{Tujuan Penelitian}

Sedangkan tujuan penelitian ini adalah untuk mendeskripsikan bentuk, peran, dan hambatan partisipasi masyarakat dalam meningkatkan mutu pendidikan di Madrasah Ibtidaiyah Islahul Muta'allim Pagutan Kota Mataram.

\section{Manfaat Penelitian}

\section{Secara Teoritis}

Secara teoritis hasil penelitian diharapkan dapat memperkaya khazanah ilmu pengetahuan tentang peran partisipasi masyarakat dalam meningkatkan mutu pendidikan madrasah, sehingga dapat dijadikan sebagai konsep dan langkah alternatif dalam pengembangan manajemen madrasah yang berkaitan dengan partisipasi masyarakat.

\section{Secara Praktis}

Secara praktis hasil penelitian ini dapat dijadikan acuan bagi berbagai kalangan yang berkepentingan dengan peran partisipasi masyarakat dalam meningkatkan mutu pendidikan madrasah. Kegunaan praktis penelitian ini diantaranya bagi peneliti sendiri, kepala madrasah, komite madrasah, lembaga pendidikan yang bersangkutan, guru-guru madrasah, dan masyarakat, penelitian ini dapat dijadikan sebagai bahan pertimbangan dalam upaya pengembangan dan peningkatan mutu pendidikan di madrasah.

\section{E. Kerangka Teoritik}

\section{Pengertian Partisipasi Masyarakat}

Secara etimologis, kata partisipasi berarti perihal turut berperan serta dalam suatu kegiatan atau keikutsertaan atau peran serta ${ }^{3}$. Menurut Made Pidarta ${ }^{4}$, partisipasi adalah pelibatan seseorang atau beberapa orang dalam suatu kegiatan. Keterlibatan dapat berupa keterlibatan mental dan emosi serta fisik dalam menggunakan segala kemampuan yang dimilikinya (berinisiatif) dalam segala kegiatan yang dilaksanakan serta mendukung percepatan tujuan dan tanggungjawab atas segala keterlibatan.

${ }^{3}$ Departemen Pendidikan Nasional, Kamus Besar Bahasa Indonesia,(Balai Pustaka, Jakarta. 2001), 831.

4 Dalam Siti Irene Astuti Dwiningrum, Desentralisasi dan Partisipasi Masyarakat Dalam Pendidikan, (Pustaka Pelajar, Yogyakarta.2011), 50. 
Sedangkan menurut Huneryear dan $\mathrm{Hecman}^{5}$ partisipasi adalah sebagai keterlibatan mental dan emosional individu dalam situasi kelompok yang mendorongnya memberi sumbangan terhadap tujuan kelompok serta membagi tanggung jawab bersama mereka.

Hubungan Masyarakat (Humas) menurut Nasution ${ }^{6}$ adalah segenap kegiatan dan teknik/kiat yang digunakan organisasi atau atau individu untuk menciptakan atau memelihara suatu sikap dan tanggapan yang baik dari pihak luar terhadap keberadaan dan aktivitasnya.

Strategi pelibatan masyarakat dalam kegiatan pendidikan secara garis besar dibagi menjadi dua, yaitu :

1) Keterlibatan secara individual, seperti membuka kesempatan dan konsultasi seluasluasnya bagi orang tua peserta didik untuk datang ke sekolah/maadrasah.

2) Keterlibatan secara organisatoris, yaitu keterlibatan melalui komite sekolah/madrasah, organisasi alumni, dunia usaha/kerja, dan melalui hubungan dengan instansi lain. ${ }^{7}$

Lebih lanjut dijelaskan bahwa bentuk keterlibatan masyarakat secara organisatoris, misalnya untuk kegiatan pembangunan fisik, orang tua peserta didik yang arsitektur diminta bantuannya membuat design bangunan, pemusik, pelukis, dramawan, dan olahragawan dilibatkan dalam kegiatan ekstra kurikuler, praktisi hukum dilibatkan dalam masalah hukum, dan tata tertib dan profesilain yang mendukung kemajuan lembaga pendidikan.

Madrasah dan masyarakat merupakan dua komunitas yang saling melengkapi bahkan ikut memberikan warna terhadap perumusan model pembelajaran tertentu di madrasah. Madrasah mempunyai peran dalam proses pelestarian dan pemindahan nilai-nilai kultur pendidikan, ilmu pengetahuan, teknologi, seni, dan agama yang dianut para guru dan peserta didiknya kepada generasi penerus.

\section{Bentuk Partisipasi Masyarakat}

Dalam iklim yang kompetitif sekarang ini, sulit bagi organisasi untuk dapat hidup dengan baik jika tidak memiliki kemampuan untuk mengubah diri dengan cepat dan mampu berkembang seiring dengan berbagai tuntutan stakeholder. Kondisi ini berlaku hampir pada keseluruhan organisasi baik yang bersifat profit maupun nonprofit. Madrasah sebagai lembaga pendidikan yang termasuk lembaga nonprofit juga tidak terlepas dari

${ }^{5}$ Ibid, 51.

6 Zulkarnaen Nasution, Manajemen Humas di Lembaga Pendidikan; Konsep,Fenomena dan Aplikasinya, (UMM press, Malang. 2011), 9.

${ }_{7}$ Baharuddin, Manajemen Pendiiken Islam, (UIN Maliki Press, Malang. 2010), 91. 
fenomena ini, itulah sebabnya dalam banyak hal lembaga pendidikan harus mengetahui berbagai harapan dan kebutuhan stakeholder. ${ }^{8}$

Masyarakat sebagai suatu komunitas yang dapat memberi warna terhadap madrasah memberi perhatian dalam upaya pengembangan rencana strategis lembaga tersebut. Menurut Gaventa dan Valderma ${ }^{9}$ bahwa ada tiga tradisi konsep partisipasi bila dikaitkan dengan praksis pembangunan masyarakat yang demokratis, yaitu partisipasi politik, partisipasi sosial, dan partisipasi warga.

Partisipasi politik seringkali dihubungkan dengan proses politik yang demokratik, yang melibatkan interaksi perseorangan dan organisasi, biasanya partai politik dengan negara. Partisipasi politik dihubungkan dengan demokrasi politik yang mengedepankan prinsip perwakilan dan partisipasi langsung diungkapkan dalam tindakan seorang individu atau kelompok terorganisasi untuk melakukan pemungutan suuara, kampanye, protes atau mempengaruhi wakil-wakil pemerintah.

Partisipsi sosial lebih berorientasi pada perencanaan dan implementasi pembangunan. Partisipasi ini ditempatkan sebagai keterlibatan masyarakat terutama yang terkait dengan proses pembangunan dalam konsultasi data pengambilan keputusan pada semua tahapan siklus proyek pembangunan dari implementasi, pemantauan dan evaluasi. Ada beberapa asumsi yang dipakai untuk mendorong partisipasi sosial yaitu : 1) rakyatlah yang paling tahu kebutuhannya maka rakyatlah yang mempunyai hak untuk menentukan pembangunan di lokalnya ,2) partisipasi ini dapat menjamin kepentingan dan suara-suara kelompok yang selama ini dimarjinalkan, 3) Partisipasi sosial dalam pengawasan terhadap proses pembangunan dapat menjamin tidak terjadinya berbagai penyimpangan, penurunan kualitas dan kuantitas pembangunan.

Partisipasi masyarakat, partisipasi ini menekankan pada "partisipasi langsung” warga dalam pengambilan keputusan pada lembaga dan proses kepemerintahan. Partisipasi masyarakat telah mengalihkan konsep partisipasi menuju suatu kepedulian dengan berbagai bentuk keikutsertaan warga dalam pembuatan kebijaksanaan dan pengambilan keputusan di berbagai gelanggang kunci yang mempengaruhi kehidupan warga masyarakat.

\footnotetext{
8 Muhaimin, Manajemen Pendidikan; Aplikasinya Dalam Penyusunan Rencana pengembangan Sekolah/madrasah,(Prenada Media Group, Jakarta. 2010), 23.

9 Dalam Siti Irene Astuti Dwiningrum, Desentralisasi dan Partisipasi Masyarakat Dalam Pendidikan, (Pustaka Pelajar, Yogyakarta.2011), 53.
} 
Ada beberapa bentuk partisipasi masyarakat terhadap dunia pendidikan sebagaimana yang diungkapkan oleh Baharuddin ${ }^{10}$ sebagai berikut :

1. Partisipasi dalam Komite Madrasah

Menurut UUSPN No. 20 tahun 2003 pasal 56 ayat 3, komite sekolah/madrasah adalah sebagai lembaga mandiri yang dibentuk dan berperan dalam meningkatkan mutu pelayanan dengan memberikan pertimbangan, arah dan dukungan tenaga, sarana dan prasarana serta pengawasan pendidikan pada tingkat satuan pendidikan.

Lebih lanjut Sagala ${ }^{11}$ menjelaskan bahwa kontribusi komite sekolah/madrasah antara lain menyangkut :

a. Penyusunan perencanaan strategik sekolah/madrasah, yaitu strategi pembangunan sekolah/madrasah untuk perspektif 3-4 tahun ke depan.

b. Penyusunan perencanaan tahunan sekolah/madrasah.

c. Mengadakan pertemuan terjadwal untuk menampung dan membahas berbagai kebutuhan, masalah, aspirasi dan ide-ide yang disampaikan oleh anggota komite sekolah/madrasah.

d. Memikirkan upaya-upaya yang mungkin dilakukan untuk memajukan sekolah/madrasah terutama yang menyangkut fasilitas.

e. Mendorong sekolah/madrasah melakukan internal monitoring (school self assessment) dan melaporkannya untuk dibahas dalam forum komite sekolah/madrasah.

f. Membahas hasil-hasil tes. standar yang dilakukan oleh lembaga eksternal dalam upaya menjaga quality assurance.

g. Membahas laporan tahunan sekolah/madrasah sehingga memperoleh gambaran yang tepat atas penerimaan komite sekolah/madrasah

\section{Partisipasi dalam Dewan Pendidikan}

Menurut Undang-undang No. 20 tahun 2003 tentang Sisdiknas, Dewan Pendidikan adalah lembaga mandiri yang beranggotakan berbagai unsur masyarakat yang peduli pendidikan. Dilihat dari aspek legalitasnya, Dewan Pendidikan menjadi lebih kuat karena telah diwadahi dalam pasal 56 ayat 2 Undang-undang No. 20 tahun 2003, yang menegaskan bahwa : Dewan Pendidikan sebagai lembaga mandiri dibentuk dengan memeberikan pertimbangan, arah dan dukungan tenaga, sarana dan prasarana serta pengawasan

${ }^{10}$ Baharuddin, Manajemen Pendiikan Islam, (UIN Maliki Press, Malang. 2010), 93.

11 Syaiful Sagala, Manajemen Strategik dalam Peningkatan Mutu Pendidikan, (Al-Fabeta, bandung, 2010), 241. 
pendidikan pada tingkat nasional, provinsi dan kabupaten/kota yang tidak mempunyai hubungan hierarkis.

Tujuan dibentuknya Dewan Pendidikan menurut Sagala ${ }^{12}$ adalah sebagai berikut :

a. Mewadahi dan menyalurkan aspirasi dan prakarsa masyarakat dalam melahirkan kebijakan dan program pendidikan di kabupaten/kota.

b. Meningkatkan tanggung jawab dan peran serta aktif dari seluruh lapisan masyarakat dalam penyelenggaraan pendidikan.

c. Menciptakan suasana pelayanan pendidikan yang bermutu di daerah kabupaten/kota dan satuan pendidikan.

\section{Partisipasi Masyarakat dalam Meningkatkan Mutu Pendidikan}

Peningkatan mutu menjadi semakin penting bagi institusi yang digunakan untuk memperoleh kontrol yang lebih baik melalui usahanya sendiri. Institusi/lembaga pendidikan harus mendemonstrasikan bahwa mereka mampu memberikan pendidikan yang bermutu kepada peserta didik. Penentuan label/predikat bermutu dari suatu institusi salah satunya dapat ditentukan oleh konsumen (pengguna lulusan).

Organisasi-organisasi yang menganut konsep Total Quality Management (TQM) menurut Edward ${ }^{13}$ melihat mutu sebagai sesuatu yang didefinisikan oleh pelangganpelanggan mereka. Pelanggan adalah wasit terhadap mutu dan institusi sendiri tidak akan mampu bertahan lama tanpa mereka. Institusi harus menggunakan semua cara untuk mengeksplorasi kebutuhan pelanggannya.

Peningkatan mutu pendidikan terutama di madrasah merupakan sasaran utama dari seluruh proses yang dilaksanakan institusi tersebut secara berkelanjutan. Seringkali upaya peningkatan mutu pendidikan terhalang oleh kualitas pendidikan yang rendah, sehingga berdampak pada rendahnya kualitas sember daya manusia (SDM).

Hal tersebut sebagaimana dinyatakan oleh Muhaimin ${ }^{14}$ bahwa rendahnya kualitas pendidikan Islam akan berdampak pada rendahnya kualitas sumber daya manusia (SDM) yang mampu berkompetisi di dunia global, dan sekaligus akan berdampak pula pada rendahnya produktivitas (termasuk di dalamnya produktivitas iptek) dan pendapatan para warga negaranya. Atas dasar itulah, maka keberadaan lembaga pendidikan Islam Indonesia sangat merindukan jaringan kerjasama dengan lembaga-lembaga lain yang sudah mapan baik secara nasional maupun internasional.

12 Ibid, 248.

${ }^{13}$ Edward Sallis, Total Quality Management In Education,(Ircisode, Yogyakarta,2010), 55.

14 Muhaimin, Manajemen Pendidikan; Aplikasinya Dalam Penyusunan Rencana pengembangan Sekolah/madrasah,(Prenada Media Group, Jakarta. 2010), 20. 
Lebih lanjut Muhaimin ${ }^{15}$ menyatakan bahwa kerjasama semacam itu sebagai upaya pemberdayaan dan pencerahan sistem pendidikan Islam. Pemberdayaan dan pencerahan ini tentunya diarahkan pada pembenahan dan perbaikan sistem pendidikan Islam selaras dengan trend perkembangan kontemporer, sehingga menjadi suatu model pendidikan Islam yang mampu membangun SDM yang berkualitas, sekaligus mampu meningkatkan kualitas produktivitas dan pendapatan warga negaranya.

Pembenahan dan perbaikan sistem pendidikan Islam yang selaras dengan trend perkembangan kontemporer membutuhkan partisipasi aktif seluruh komponen internal madrasah maupun ekternal yaitu masyarakat. Sebagaimana dimaklumi bersama bahwa pembaruan pendidikan yang sedang digalakkan pemerintah saat ini sangat menekankan pada relevansi pendidikan. Madrasah harus dibuat lebih relevan dengan lingkungan siswa dan pengembangan kurikulum harus sesuai dengan keadaan daerah dan wilayah. Tujuannya agar madrasah tidak terisolasi dengan masyarakat dan madrasah harus berorientasi kepada kenyataan kehidupan dan masalah masyarakat. Karena itu hubungan antar madrasah dengan masyarakat yang baik harus menjadi perhatian terus menerus dari setiap kepala madrasah dan stafnya.

Hubungan masyarakat atau yang dikenal dengan term "humas" memiliki peran strategis dalam upaya peningkatan mutu lembaga pendidikan. Masyarakat yang dimaksud disini bisa orang tua murid atau masyarakat umum ataupun pihak yang berada di sekitar lingkungan madrasah. Kedudukan Humas dinilai penting, sebab dengan kehadiranya, kesuksesan dan keberhasilan sebuah institusi akan dapat tercapai dengan baik dan maksimal. Disamping itu, banyak disebutkan bahwa keberhasilan pekerjaan dan tindakan yang dilakukan lembaga pendidikan, segalanya tergantung pada kepercayaan masyarakat terhadap pekerjaan dan tindakan itu. Maka sering dikatakan bahwa "in a democraty, the succes of anything depends upon public confidence and public understanding". ${ }^{16}$ Semakin tinggi tingkat kepercayaan masyarakat terhadap lembaga pendidikan, maka akan memberikan pula pengaruh keberhasilan pengembangan lembaga tersebut.

Dalam hal ini, pencapaian target kurikulum hanya merupakan salah satu aspek yang dapat dijadikan sebagai bahan rujukan dalam penentuan kualitas pendidikan. Berdasarkan kenyataan tersebut, maka pelibatan berbagai pihak terkait mutlak diperlukan. Hal ini sesuai dengan ketentuan yang menyatakan bahwa pendidikan adalah tanggung jawab bersama

\footnotetext{
15 Ibid, 20.

${ }^{16}$ Baharuddin, Manajemen Pendiikan Islam, (UIN Maliki Press, Malang. 2010), 39.
} 
antar keluarga, masyarakat dan pemerintah. Sehubungan dengan itu, masyarakat yang di dalamnya termasuk kelompok agama dan swasta mempunyai peranan yang sangat penting dalam pendidikan Indonesia.

Keikutsertaan dan kesadaran masyarakat untuk memikul tanggung jawab pendidikan bukan sekedar harapan tetapi merupakan suatu tuntutan yang mendesak yang harus diwujudkan dalam kegiatan-kegiatan nyata di lapangan. Partisipasi masyarakat dalam pendidikan, baik dalam lingkup masyarakat kecil maupun dalam skala yang lebih luas sebenarnya telah ada sejak dulu, yang tercermin dalam berbagai bentuk dan ekpresi di masyarakat.

Melihat betapa pentingnya partisipasi masyarakat dalam bidang pendidikan, maka perlu ditingkatkan lagi baik kualitas dan intensitasnya, bentuk pelibatan maupun jangkauannya, yang kesemua itu hanya akan terwujud apabila terdapat saling pengertian antara pihak-pihak yang terkait, di antaranya pihak pemerintah, sekolah, orang tua, dan masyarakat.

Dengan derasnya arus globalisasi sekarang ini, maka pengembangan lembaga pendidikan Islam secara khusus madrasah perlu mengantisipasi berbagai hal berikut dalam rangka meningkatkan daya saing dan kualitas pendidikan, yaitu : 1) Perlunya internasionalisasi pendidikan Islam, 2) Perlunya manajemen pendidikan Islam yang berdasarkan kebutuhan pasar kerja, 3) Perlunya manajemen pendidikan Islam secara terpadu antara pendidikan formal dan nonformal, keterpaduan antara riset, pengajaran dan pelayanan, 4) Perlunya mengembangkan keterampilan terjual, dalam arti mampu menciptakan dan menawarkan jenis pelatihan dan konsultasi yang sangat diperlukan oleh institusi-institusi terkait, user (para pengguna lulusan) atau stakeholders pada umumnya, 5) Perlunya komersialisasi riset, dalam arti untuk menghimpun sumberdaya yang ada guna kepentingan masyarakat, 6) Agar lembaga pendidikan Islam mampu memacu dan memasuki abad persaingan yang semakin ketat, maka perlu mengembangkan program khusus/spesifik sesuai dengan potensi yang dimilikinya ${ }^{17}$.

Komitmen untuk menjadikan partisipasi masyarakat sebagai bagian yang penting dalam penyelenggaraan pendidikan nasional memang sudah cukup jelas sebagaimana digariskan dalam Undang-Undang Sistem Pendidikan Nasional (UUSPN) yang menyatakan bahwa pendidikan merupakan tanggung jawab bersama antara keluarga, masyarakat dan

17 Muhaimin, Manajemen Pendidikan; Aplikasinya Dalam Penyusunan Rencana pengembangan Sekolah/madrasah,(Prenada media Group, Jakarta. 2010), 21-22. 
pemerintah, yang berlaku pula dalam hal biaya. Namun bukan hanya pada tingkat yuridis formal, lebih dari itu ada persoalan yang harus segera ditangani berkaitan dengan pelibatan masyarakat dalam pendidikan seperti dalam hal pola manajemen dan standar mutu pengelolalan.

\section{F. Metode Penelitian}

\section{Pendekatan dan Jenis Penelitian}

Penelitian ini ingin mengungkap fenomena tentang peran partisipasi masyarakat dalam meningkatkan mutu pendidikan madrasah, dalam hal ini paradigma yang tepat untuk mendeskripsikan dan menganalisa hal tersebut adalah dengan pendekatan kualitatif dengan rancangan studi kasus.

Dalam penelitian kualitatif, proses penelitian berbentuk siklus, dimana pengumpulan dan analisis data berlangsung secara simultan, lebih mementingkan kedalaman daripada keluasan cakupan penelitian. Observasi dan wawancara mendalam bersifat sangat utama dalam proses pengumpulan data, serta peneliti itu sendiri merupakan instrumen utama. Seperti yang ditegaskan Moleong ${ }^{18}$ bahwa salah satu ciri utama penelitian kualitatif adalah orang sebagai alat yang mengumpulkan data. Hal itu dilakukan dalam pengamatan berperanserta, wawancara mendalam, pengumpulan dokumen, foto, dan sebagainya. Seluruh metode itu pada dasarnya menyangkut hubungan peneliti dengan orang atau subjek penelitian.

Sedangkan jenis penelitian yang digunakan adalah fenomenologik-naturalistik. Secara paradigmatik, metode penelitian kualitatif berada di bawah payung paradigma interpretivisme, atau fenomenologisme. Menurut Muhadjir ${ }^{19}$ aliran fenomenologi menyatakan bahwa obyek ilmu itu tidak terbatas pada yang empirik (sensual), melainkan mencakup fenomena yang tidak lain daripada persepsi, pemikiran, kemauan, dan keyakinan subyek tentang sesuatu di luar subyek. Menurut pandangan fenomenologik-naturalistik berarti memahami arti peristiwa dan kaitan-kaitannya terhadap orang-orang dalam situasi-situasi tertentu. Penelitian fenomenologis melihat secara dekat interpretasi individual tentang pengalaman-pengalamannya. Dalam hal ini peneliti berusaha memahami makna dari sebuah pengalaman dari perspektif partisipan. ${ }^{20}$

Dengan demikian penelitian ini berusaha untuk berinteraksi dengan subjek penelitiannya secara alamiah, tidak menonjol, dan dengan cara yang tidak memaksa.

${ }^{18}$ Moleong, Lexi.J. Metodologi Penelitian Kualitatif,(Bandung : PT. Remaja Rosdakarya,2000), 91.

${ }^{19}$ Noeng Muhadjir. Metodologi Penelitian Kualitatif (Edisi IV), (Yogyakarta : Rake sarasin, 2000), 17.

${ }^{20}$ Moleong, Lexi.J. Metodologi ..., 9. 
Penelitian ini tertarik untuk meneliti orang-orang dalam latar alamiah tentang bagaimana mereka berfikir dan bertindak menurut cara mereka. Dalam hal ini diusahakan agar jangan sampai terjadi oleh kehadiran seorang peneliti, tindakan dan cara para subjek menjadi berubah.

\section{Lokasi Penelitian}

Penelitian ini dilakukan di Madrasah Ibtidaiyah Islahul Muta'allim Pagutan Kota Mataram. Madrasah tersebut merupakan lembaga pendidikan Islam tingkat dasar yang bernaung di bawah yayasan perguruan Islahul Muta'allim Pagutan kota Mataram. Madrasah ini dalam kiprahnya telah berperan membentuk sumber daya manusia melalui berbagai aktivitas dan program pendidikan agar tidak tertinggal dengan kemajuan perkembangan lembaga pendidikan lainnya.

Melihat pada realitas lainnya, walaupun madrasah berdiri dengan status swasta, namun antusiasme masyarakat sangat kuat untuk menyekolahkan putra-putrinya di madrasah tersebut. Padahal kalau dilihat secara letak geografis, madrasah tersebut bersebelahan dengan Sekolah Dasar Negeri, hal ini menunjukkan bahwa masyarakat memiliki daya tarik tersendiri dan kepercayaan atas keberadaan dan kualitas pendidikan yang terdapat di dalamnya.

Disamping itu, keberadaan lembaga pendidikan Islam ini sangat diperhatikan oleh seluruh lapisan masyarakat, terutama masyarakat yang berada di sekitarnya. Wujud perhatian dan kepedulian masyarakat itu diekspesikan melalui berbagai bentuk partisipasi atau keterlibatan masyarakat dalam menyusun dan melaksanakan program kelembagaan baik melalui keterlibatan secara individu maupun secara organisatoris.

\section{Data dan Sumber Data}

Data merupakan keterangan-keterangan tentang suatu fakta ${ }^{21}$. Data adalah keterangan atau bahan nyata yang dapat dijadikan dasar kajian (analisis atau kesimpulan). ${ }^{22}$ Dalam penelitian ini data dapat dibagi menjadi dua, yaitu data tertulis dan data yang tidak tertulis. Jenis data yang diperoleh dapat berupa kata-kata, perilaku dan selebihnya adalah data tambahan seperti dokumen dal lain-lainnya. Moleong ${ }^{23}$ menjelaskan bahwa "dalam penelitian kualitatif ungkapan-ungkapan, aktivitas-aktivitas dan fenomena-fenomena yang

${ }^{21}$ Dalam Andi Prastowo, Memahami Metode-metode Penelitian, (Jogjakarta : Ar Ruzz Media, 2011), 31.

22 Tim Penulis Pedoman Penulisan Tesis dan Disertasi, Pedoman Penulisan Tesis dan Disertasi, (Malang: Program Pascasarjana Universitas Islam Negeri Maulana Malik Ibrahim Malang, 2009), 8.

${ }^{23}$ Moleong, Lexi.J. Metodologi Penelitian Kualitatif, (Bandung : PT. Remaja Rosdakarya, 2000), 112. 
muncul merupakan data utama, sedangkan data tambahannya dapat berupa dokumendokumen tertulis".

Dalam penelitian ini data dan sumber data adalah sebagai berikut :

1. Data tentang bentuk partisipasi masyarakat dalam meningkatkan mutu pendidikan madrasah. Peneliti memperoleh data tersebut dari ketua yayasan, ketua komite, kepala madrasah, para dewan guru, dan masyarakat melalui observasi, wawancara, dan dokumentasi tertulis.

2. Data tentang peran partisipasi masyarakat dalam meningkatkan mutu pendidikan madrasah. Peneliti memperoleh data tersebut dari ketua yayasan, ketua komite, kepala madrasah, para dewan guru, dan masyarakat melalui observasi, wawancara, dan dokumentasi tertulis.

3. Data tentang hambatan yang dihadapi masyarakat dalam berpartisipasi untuk meningkatkan mutu pendidikan madrasah dapat diperoleh ketua yayasan, kepala madrasah, para dewan guru, dan masyarakat melalui observasi, wawancara, dan dokumentasi tertulis.

\section{Teknik Pengumpulan Data}

\section{Observasi Partisipan}

Observasi partisipan dilakukan oleh peneliti dengan berpartisipasi sebagai pengamat dalam berbagai kegiatan madrasah dan masyarakat dalam berpartisipasi untuk membantu keberlangsungan pendidikan madrasah. Sebagai pengamat partisipan peneliti mengamati fenomena yang terjadi pada masyarakat terutama yang berkenaan dengan bentuk partisipasi mereka terhadap madrasah, peran partisipasi mereka dalam meningkatkan mutu pendidikan madrasah, dan hambatan yang mereka hadapi dalam berpartisipasi untuk meningkatkan mutu pendidikan madrasah.

Setiap observer memiliki gaya yang berbeda-beda. Salah satu perbedaan adalah derajat keterlibatan peneliti, baik dengan orang maupun kegiatan-kegiatan yang diamati. Menurut Spradley ${ }^{24}$ terdapat 3 derajat keterlibatan, yaitu tanpa keterlibatan (no involvement), keterlibatan rendah (low), dan keterlibatan tinggi (bight). Variasi tercermin dalam 5 tingkat partisipasi, yaitu: non partisipasi (nonparticipation), partisipasi pasif (passive participation), partisipasi moderat (moderate participation), partisipasi aktif (active participation), dan partisipasi lengkap (complete participation).

${ }^{24}$ Dalam Syamsuddin AR, Metode Penelitian Pendidikan Bahasa, (Bandung: Diterbitkan atas Kerjasama Program Pascasarjana Universitas Pendidikan Indonesia (UPI) dengan PT. Remaja Rosdakarya, 2011), 100. 
Teknik observasi yang paling lazim dipakai dalam penelitian kualitatif adalah observasi partisipatif. Fokus perhatian yang paling esensial dari penelitian kualitatif adalah pemahaman dan kemampuan peneliti dalam membuat makna atas sesuatu kejadian atau fenomena pada situasi yang tampak. Melihat fenomena ini, khususnya pada saat pengumpulan data dengan menggunakan observasi partisipatif, peneliti kualitatif harus melakukan pengamatan secara cermat terhadap perilaku subjek, baik dalam suasana formal maupun santai.

Dengan observasi partisipan peneliti dapat melihat secara langsung bagaimana bentuk partisipasi masyarakat dan perannya dalam meningkatkan mutu pendidikan madrasah, serta hambatan yang dihadapi masyarakat dalam berpartisipasi untuk meningkatkan mutu pendidikan madrasah di Madrasah Ibtidaiyah Islahul Muta'allim Pagutan Mataram.

\section{Wawancara Mendalam}

Wawancara merupakan percakapan yang memiliki maksud tertentu, percakapan tersebut dilakukan oleh dua pihak, yaitu pewawancara (interviewer) yang mengajukan pertanyaan atau persoalan kepada responden dan yang diwawancarai (interviee). Moleong $^{25}$ menyatakan bahwa mengadakan wawancara berarti mengkonstruksi mengenai orang, kejadian, kegiatan, organisasi, perasaan, motivasi, tuntutan, kepedulian dan lain-lain. Dengan demikian, peneliti sangat memerlukan tehnik wawancara untuk menggali data atau informasi dari subjek penelitian.

Tehnik wawancara yang paling tepat untuk menggali data-data tersebut adalah wawancara mendalam (deep interview). Dalam wawancara mendalam ini, peneliti mengajukan beberapa pertanyaan yang terkait dengan fokus penelitian, kemudian subjek penelitian diberikan kebebasan untuk memberikan jawaban. Namun demikian peneliti senantiasa memberikan arahan dan motivasi dalam menyampaikan jawabannya.

Dalam kaitannya dengan data tentang bentuk partisipasi masyarakat, perannya, dan hambatan yang dihadapi masyarakat dalam berpartisipasi untuk meningkatkan mutu pendidikan madrasah di Madrasah Ibtidaiyah Islahul Muta'allim Pagutan Mataram, peneliti menggunakan wawancara tak terstruktur.

Wawancara tak terstruktur digunakan untuk menemukan informasi yang bukan baku atau informasi tunggal. Wawancara semacam ini sangat berbeda dari wawancara terstruktur dalam hal waktu bertanya dan cara memberikan pertanyaan dan cara

${ }^{25}$ Lexy J. Moleong, ...h. 35 
memberikan respons, yaitu jenis ini jauh lebih bebas iramanya. Responden biasanya terdiri atas mereka yang terpilih saja karena sifat-sifatnya yang khas. Biasanya mereka memiliki pengetahuan dan mendalamai situasi, dan mereka lebih mengetahui informasi yang diperlukan. ${ }^{26}$

Teknik wawancara ini dilakukan secara terbuka untuk menggali pandangan subjek penelitian tentang bentuk partisipasi masyarakat, perannya, dan hambatan yang dihadapi masyarakat dalam berpartisipasi untuk meningkatkan mutu pendidikan madrasah di Madrasah Ibtidaiyah Islahul Muta'allim Pagutan Mataram secara umum. Dimana wawancara dilakukan pada waktu dan konteks yang dianggap tepat guna mendapatkan data relevan dengan fokus penelitian.

Adapun isu pokok yang diangkat dalam wawancara merupakan cerminan dari fokus penelitian yang sudah disusun sebelumnya, yaitu: 1) bentuk partisipasi masyarakat dalam meningkatkan mutu pendidikan madrasah, 2) peran partisipasi masyarakat dalam meningkatkan mutu pendidikan madrasah, dan 3) hambatan yang dihadapi masyarakat dalam berpartisipasi untuk meningkatkan mutu pendidikan madrasah di Madrasah Ibtidaiyah Islahul Muta'allim Pagutan Mataram.

\section{Dokumentasi}

Teknik dokumentasi digunakan untuk mengumpulkan data dari sumber nonmanusia. Sumber ini terdiri atas dokumen dan rekaman. Lincoln dan Guba (1985) ${ }^{27}$ mengartikan rekaman sebagai setiap tulisan atau pernyataan yang dipersiapkan oleh atau untuk individu atau organisasi dengan tujuan membuktikan adanya suatu peristiwa. Beberapa contoh rekaman adalah nilai siswa, kurikulum, satuan pembelajaran. Adapun dokumen digunakan mengacu pada setiap tulisan atau bukan selain rekaman, yaitu tidak dipersiapkan secara khusus untuk tujuan tertentu, seperti surat-surat, buku harian, naskah, editorial surat kabar, catatan kasus, skrip televisi dan foto-foto.

Terdapat beberapa alasan mengapa digunakan sumber ini, pertama, sumber ini selalu tersedia dan murah (terutama ditinjau dari konsumsi waktu). Kedua, rekaman dan dokumen merupakan sumber informasi yang stabil, baik keakuratannya dalam merefleksikan situasi yang terjadi di masa lampau dan dapat dianalisis kembali tanpa mengalami perubahan. Ketiga, rekaman dan dokumen merupakan sumber informasi yang

\footnotetext{
26 Ibid, 190-191.

${ }^{27}$ Dalam Syamsuddin AR, Metode Penelitian Pendidikan Bahasa..., 108.
} 
kaya, secara kontekstual relevan dan mendasar dalam konteksnya. Keempat, sumber inni sering merupakan pernyataan yang legal yang dapat memenuhi akuntabilitas. ${ }^{28}$

Dengan dokumentasi, peneliti dapat mencatat berbagai informasi tentang bentuk partisipasi masyarakat, perannya, dan hambatannya dalam meningkatkan mutu pendidikan madrasah, informasi tentang Madrasah Ibtidaiyah Islahul Muta'allim Pagutan Mataram yang meliputi guru-guru, kegiatan madrasah, foto-foto, dokumen madrasah, struktur organisasi, job deskripsi dan dokumen lainnya yang dianggap penting. Data-data tersebut dijadikan bahan untuk melakukan verifikasi terhadap realitas partisipasi yang dilakukan oleh masyarakat dalam meningkatkan mutu pendidikan madrasah.

\section{Teknik Analisis Data}

Untuk melakukan analisis data, penelitian ini menggunakan teknik analisis data model interaktif seperti yang dikembangkan oleh Miles dan Huberman (1994) ${ }^{29}$ sebagai berikut:

\section{Data Collection (Pengumpulan Data)}

Langkah pertama, memusatkan perhatian pada kegiatan observasi, kegiatan observasi tidak hanya dilakukan terhadap kenyataan-kenyataan yang terlihat, tetapi juga terhadap yang didengar dan dirasakan. Berbagai macam ungkapan atau pernyataan yang terlontar dalam percakapan sehari-hari juga termasuk bagian dari kenyataan yang bisa diobservasi. Kesemuanya bisa dipandang sebagai suatu hamparan kenyataan yang mungkin saja bisa diangkat sebagai “tabel hidup”. Hal itu dilakukan untuk tujuan deskripsi atau untuk tujuan verifikasi terhadap fenomena.

Peneliti mengumpulkan data dari berbagai sumber dengan menggunakan teknik observasi, wawancara mendalam, dan dokumentasi. Pengumpulan data dilakukan oleh peneliti secara berkelanjutan dengan terus melakukan wawancara dengan para guru, kepala madrasah, dan masyarakat di lingkungan Karang Genteng Pagutan Mataram. Proses wawancara tersebut peneliti rekam dengan recorder untuk kemudian dibuat transkripnya, selain itu juga peneliti mengambil gambar/foto sebagai bukti yang memperkuat keseluruhan proses yang dilakukan peneliti.

Selain melalui wawancara, peneliti mengobservasi aktivitas masyarakat di lingkungan tersebut untuk melihat keterlibatan mereka dalam upaya meningkatkan mutu

\footnotetext{
${ }^{28} \mathrm{Ibid}, 109$

${ }^{29}$ Ibid, 79.
} 
pendidikan di madrasah, selain itu juga peneliti mengobservasi madrasah dalam melakukan berbagai aktivitasnya. Peneliti mencatat peristiwa-peristiwa yang terjadi pada saat masyarakat terlibat dalam berbagai kegiatan madrasah, peneliti juga mencatat peristiwa-peristiwa yang terjadi pada saat madrasah melakukan kegiatan. Peneliti juga mengumpulkan data-data melakui teknik dokumentasi, peneliti meminta data-data madrasah yang berbentuk dokumen kepada wakil kepala madrasah.

\section{Data Reduction (Reduksi Data)}

Data yang diperoleh dari lapangan jumlahnya cukup banyak, untuk itu maka perlu dicatat secara teliti dan rinci. Semakin lama peneliti ke lapangan, maka jumlah data akan semakin banyak, kompleks dan rumit. Untuk itu perlu segera dilakukan analisis data melalui reduksi data. Mereduksi data berarti merangkum, memilih hal-hal yang pokok, menfokuskan pada hal-hal yang penting, dicari tema dan polanya. Dengan demikian data yang telah direduksi akan memberikan gambaran yang lebih jelas, dan mempermudah peneliti untuk melakukan pengumpulan data selanjutnya, dan mencarinya bila diperlukan. Reduksi data dapat dibantu dengan peralatan elektronik seperti komputer mini, dengan memberikan kode pada aspek-aspek tertentu.

Pada bagian ini peneliti mengecek dan menganalisis data yang sudah terkumpul melalui ketiga teknik pengumpulan data, hal ini peneliti lakukan untuk memilah dan memilih serta mengelompokkan data-data tersebut kedalam bagian-bagian sesuai dengan permasalahan penelitian. Proses ini memudahkan peneliti untuk melakukan penyajian data sesuai dengan urutannya walaupun data-data tersebut diambil dari berbagai sumber dan berbagai teknik.

\section{Data Display (Penyajian Data)}

Setelah data direduksi, maka langkah selanjutnya adalah mendisplaykan data. Dalam penelitian kualitatif, penyajian data dapat dilakukan dalam bentuk uraian singkat, bagan, hubungan antar kategori, flowchart dan sejenisnya. Dalam hal ini Miles and Huberman $(1984)^{30}$ menyatakan "the most frequent form of display data for qualitative research data in the past has bee narrative text". Yang paling sering digunakan untuk menyajikan data dalam penelitian kualitatif adalah dengan teks yang bersifat naratif.

Dengan mendisplaykan data, maka akan memudahkan untuk memahami apa yang terjadi, merencanakan kerja selanjutnya berdasarkan apa yang telah dipahami tersebut. Selain dengan teks naratif, display data juga dapat dengan grafik, matrik, network

\footnotetext{
${ }^{30}$ Dalam Sugiono..., 249.
} 
(jaringan kerja) dan chart. Untuk mengecek apakah peneliti telah memahami apa yang didisplaykan.

Pada proses ini peneliti memaparkan data melalui deskripsi yang menjelaskan fakta yang terjadi di masyarakat lingkungan Karang Genteng Pagutan Mataram dalam kaitannya dengan keterlibatan mereka dalam meningkatkan mutu pendidikan di madrasah. Peneliti berupaya menarasikan fakta dengan bahasa peneliti dengan terlebih dahulu memberikan makna terhadap fenomena atau gejala yang terjadi di lokasi peneitian. Peneliti memaparkan hasil wawancara dan observasi secara apa adanya dengan memperhatikan fokus penelitian, karena seringkali wawancara bias terhadap permasalahan yang diangkat. Dalam posisi ini, peneliti hanya menarasikan dan memaparkan bagianbagian yang penting saja.

\section{Conclusion Drawing/Verification}

Langkah selanjutnya adalah penarikan kesimpulan dan verifikasi. Kesimpulan awal yang dikemukakan masih bersifat sementara, dan tidak akan berubah bila tidak ditemukan bukti-bukti yang kuat yang mendukung pada tahap pengumpulan data berikutnya. Tetapi apabila kesimpulan awal didukung oleh bukti-bukti yang valid dan konsisten saat peneliti kembali ke lapangan untuk mengumpulkan data, maka kesimpulan yang dikemukakan merupakan kesimpulan yang kredibel.

Bagian akhir dari kegiatan analisis adalah peneliti menarik kesimpulan, penarikan kesimpulan peneliti lakukan dalam berbagai tahapan. Setelah peneliti mendisplay data, peneliti menarik kesimpulan sementara sambil mencari dan melengkapi data-data yang sudah terkumpul sebelumnya. Jika data sudah dianggap lengkap oleh peneliti, maka peneliti melakukan verifikasi kembali terhadap kesimpulan sementara dengan memperhatikan data-data dukung yang baru. Sehingga peneliti dapat menarik kesimpulan yang bersifat kredibel.

\section{Pengecekan Keabsahan Temuan}

Pengecekan keabsahan data dalam penelitian kualitatif mutlak dilakukan, hal tersebut dilakukan agar data yang diperoleh dapat dipertanggungjawabkan kebenarannya dengan melakukan verifikasi terhadap data tersebut. Menurut Sugiyono ${ }^{31}$ pengujian keabsahan data dalam penelitian kualitatif meliputi derajat kepercayaan (credibility), keteralihan (transferability), kebergantungan (dependability) reliabilitas, dan objektifitas (confirmability).

31 Ibid, 270. 
Dalam penelitian ini, Ada tiga kegiatan untuk mengecek keabsahan data dalam penelitian ini, yaitu: kepercayaan (credibitity), kebergantungan (dependability), dan objektifitas (confirmability).

\section{PEMBAHASAN}

1. Bentuk Partisipasi Masyarakat dalam Meningkatkan Mutu Pendidikan di Madrasah Ibtidaiyah Islahul Muta'allim Pagutan Kota Mataram.

Keberhasilan dari suatu proses peningkatan mutu pendidikan di madrasah sangat ditentukan oleh unsur-unsur yang terlibat dalam proses tersebut, yaitu madrasah sendiri dan masyarakat. Kedua unsur tersebut merupakan penggerak dari berbagai upaya tersebut, kedua unsur tersebut harus memiliki keterampilan, pengetahuan dan kesungguhan untuk merealisasikannya.

Dari hasil penelitian dan yang menjadi temuannya adalah bahwa masyarakat memiliki kepedualian terhadap pendidikan di madrasah, mereka turut berpartisipasi dengan kemampuan dan skil mereka. Bentuk partisipasi yang mereka berikan ke madrasah berupa; keterlibatan dalam hal input pembelajaran yang terkait dengan penerimaan siswa baru, keterlibatan dalam hal proses pembelajaran, hal ini terkait dengan keikutsertaan masyarakat dalam upaya membina siswa madrasah dengan berbagai kegiatan pembinaan baik di madrasah maupun di luar madrasah, dan bentuk keterlibatan mereka lainnya berupa keterlibatan dalam output pembelajaran, hal ini menyangkut keterlibatan masyarakat dalam upaya meningkatkan hasil dan prestasi yang diraih siswa.

Berbagai bentuk partisipasi masyarakat dalam upaya meningkatkan mutu pendidikan di madrasah menunjukkan bahwa ternyata suatu lembaga pendidikan, lebihlebih lembaga pendidikan yang berstatus swasta tidak dapat berdiri secara kokoh tanpa adanya dukungan, dorongan, dan keterlibatan masyarakat di dalamnya. Upaya peningkatan mutu pendidikan di madrasah bukanlah masalah yang sederhana, tetapi memerlukan keterlibatan banyak pihak termasuk di dalamnya adalah masyarakat. Dalam konteks ini, mutu pendidikan di madrasah bukan hanya terpusat pada pencapaian target kurikulum semata, akan tetapi menyangkut semua aspek yang berkenaan dengan pengetahuan, keterampilan, dan akhlakul karimah yang diharapkan oleh seluruh lapisan masyarakat.

Ghirah atau keinginan yang kuat dari masyarakat untuk turutserta membangun pendidikan di madrasah bukan tanpa alasan, secara fakta bahwa madrasah swasta dibangun berdasarkan keinginan dan perjuangan masyarakat, maka sudah selayaknya jika mereka 
berjuang untuk mempertahankan eksistensi madrasah tersebut. Kalau dicermati, pendidikan Islam setidak-tidaknya dapat dikelompokan dalam lima jenis, yaitu :

1. Pondok Pesantren atau Madrasah Diniah, yang menurut UU No.20 Tahun 2003 tentang sistem pendidikan Nasional disebut sebagai pendidikan kegamaan (Islam) formal seperti pondok pesantren/Madrsah diniah (Ula, Wustha, 'Ulya dan Ma'had Ali)

2. Madrsah dan pendidikan lanjutannya seperti IAIN/STAIN/UIN yang bernaung di bawah Departemen Agama.

3. Pendidikan usia dini/TK,Sekolah/Perguruan Tinggi yang diselenggarakan oleh dan atau berada dibawah naungan organisasi-organisasi dan yayasan Islam.

4. Pelajaran Agama Islam di Sekolah/Madrasah/Perguruan Tinggi sebagai suatu mata pelajaran atau mata kuliah dan atau sebagai program studi

5. Pendidikan Islam dalam keluarga atau tempat-tempat ibadah, dan atau forumforum/kajian keislaman, majlis taklim dan institusi-institusi lannya. ${ }^{32}$

Mengacu pada pemahaman dan pengklasifikasian di atas, maka secara kelembagaan, yang di maksud lembaga pendidikan Islam adalah pendidikan yang diselenggarakan oleh pemerintah atau masyarakat (yayasan/organisasi), yang berlandaskan dan berkarakter pada muatan-muatan nilai Islam, baik secara implisit maupun eksplisit. Di Indonesia, penyelenggaraan pendidikan di lembaga pendidikan Islam yang dikelola pemerintah atau masyarakat dan berstatus negeri atau swasta seperti Madrasah Ibtida'iyah Negeri/Swasta, Madrasah Tsanawiyah Negeri/Swasta, Madrasah Aliyah Negeri/Swasta, Perguruan Tinggi Negeri/PTS dan sejenisnya.

Dalam hal ini, masyarakat memiliki landasan yuridis faktual dalam membangun madrasah dan meningkatkan mutu pendidikan di dalamnya, sehingga mereka berharap bahwa akan lahir generasi Islami yang memiliki pengetahuan, keterampilan, dan akhlakul karimah dari madrasah yang dibangunnya tersebut. Berdasarkan kenyataan tersebut, maka pelibatan berbagai pihak terkait mutlak diperlukan. Hal ini sesuai dengan ketentuan yang menyatakan bahwa pendidikan adalah tanggung jawab bersama antar keluarga, masyarakat dan pemerintah, sebagaimana dinyatakan di sejumlah dokumen perundang-undangan pemerintah. Sehubungan dengan itu, masyarakat yang di dalamnya termasuk kelompok

32 Muhaimin, Pemikiran dan Aktualisasi Pengembangan Pendidikan Islam.(Jakarta :PT Raja Grapindo Persada,2011), 39. 
agama dan swasta mempunyai peranan yang sangat penting dalam peningkatan mutu pendidikan di madrasah.

\section{Peran Partisipasi Masyarakat dalam Meningkatkan Mutu Pendidikan di Madrasah Ibtidaiyah Islahul Muta'allim Pagutan Kota Mataram.}

Partisipasi dan kesadaran masyarakat untuk terlibat langsung memikul tanggung jawab peningkatan mutu pendidikan di madrasah bukan sekedar harapan tetapi merupakan suatu tuntutan yang mendesak yang harus diwujudkan dalam kegiatan-kegiatan nyata di lapangan. Partisipasi masyarakat dalam upaya peningkatan mutu pendidikan madrasah merupakan tradisi yang sudah berkembang sejak lama begitu lahirnya madrasah di tengahtengah masyarakat.

Melihat betapa pentingnya partisipasi masyarakat dalam peningkatan mutu pendidikan di madrasah, maka partisipasi tersebut perlu ditingkatkan baik dari sisi kualitas dan kuantitasnya. Masyarakat di sekitar madrasah yang notabenenya beragama Islam menggantungkan harapan besar kepada madrasah sebagai lembaga pendidikan Islam untuk dapat mencetak generasi Islami. Pendidikan Islam mempunyai peranan penting dalam meningkatkan kualitas sumber daya manusia. Sesuai dengan cirinya sebagai pendidikan agama, secara ideal cita-cita pendidikan Islam berfungsi dalam penyiapan sumber daya manusia yang berkualitas tinggi, baik dalam penguasaan ilmu pengatahuan dan tekhnologi, maupun dalam karakter, sikap moral, dan penghayatan dan pengamalan ajaran agama.

Dalam rangka mewujudkan fungsi ideal madrasah tersebut, untuk meningkatkan kualitas sumberdaya manusia, maka program pendidikan madrasah haruslah mengorientasikan diri kepada usaha menjawab kebutuhan dan tantangan yang muncul di tengah-tengah masyarakat, sebagai konsekwensi dari adanya perubahan-perubahan di semua segmen kehidupan manusia.

Eksistensi madrasah tidak terlepas dari peran strategis partisipasi masyarakat baik dalam hal penyusunan atau perencanaan program strategis madrasah maupun dalam hal pengawasan program madrasah. Keterlibatan masyarakat dalam pendidikan madrasah secara garis besar dibagi menjadi dua, yaitu :

3) Keterlibatan secara individual, seperti membuka kesempatan dan konsultasi seluasluasnya bagi orang tua peserta didik untuk datang ke madrasah. 
4) Keterlibatan secara organisatoris, yaitu keterlibatan melalui komite madrasah, organisasi alumni, dunia usaha/kerja, dan melalui hubungan dengan instansi lain. ${ }^{33}$

Lebih lanjut dijelaskan bahwa bentuk keterlibatan masyarakat secara organisatoris, misalnya untuk kegiatan pembangunan fisik, orang tua peserta didik yang arsitektur diminta bantuannya membuat design bangunan, pemusik, pelukis, dramawan, dan olahragawan dilibatkan dalam kegiatan ekstra kurikuler, praktisi hukum dilibatkan dalam masalah hukum, dan tata tertib dan profesi lain yang mendukung kemajuan pendidikan di madrasah.

Melihat realitas yang terjadi di lokasi penelitian, bahwa kedua komponen yaitu madrasah dan masyarakat merupakan dua komunitas yang saling melengkapi bahkan ikut memberikan warna terhadap segala prestasi yang diraih madrasah. Madrasah mempunyai peran dalam proses pelestarian dan pemindahan nilai-nilai kultur pendidikan, ilmu pengetahuan, teknologi, seni, dan agama yang dianut para guru dan peserta didiknya kepada generasi penerus sebagaimana yang diharapkan oleh masyarakat. Demikian halnya dengan masyarakat, mereka mempunyai peran yang strategis dalam membantu madrasah untuk merealisasikan segala program peningkatan mutu pendidikan.

Menurut George R Terry bahwa perencanaan adalah menetapkan pekerjaan yang harus dilaksanakan leh kelompok untuk mencapai tujuan yang digariskan. Perencanaan mencakup kegiatan pengambilan keputusan, karena termasuk pemilihan alternatif-alternatif keputusan. Diperlukan kemampuan untuk mengadakan visualisasi dan melihat ke depan guna merumuskan suatu poladari himpunan tindakan untuk masa mendatang. ${ }^{34}$

Partisipasi masyarakat merupakan keterlibatan secara aktif dan bermakna pada tingkatan-tingkatan yang berbeda diantaranya di dalam proses perencanaan yaitu proses pembentukan keputusan untuk menentukan tujuan-tujuan kemasyarakatan bagi madrasah, proses pelaksanaan program-program madrasah, dan pengawasan jalannya programprogram madrasah. Pada intinya keberhasilan perencanaan dan pelaksanaan program madrasah dapat diraih dengan adanya keterlibatan aktif masyarakat.

Disamping itu, tidak kalah pentingnya peran pengawasan yang dilakukan masyarakat terhadap madrasah. Pengawasan masyarakat dapat merangsang dan memperluas keterlibatan aktif masyarakat dalam mengawal peningkatan mutu pendidikan madrasah. Partisipasi masyarakat tersebut diantaranya dipengaruhi oleh kesadaran dari sebagian besar lapisan masyarakat dan pemimpinnya. Dalam konteks pengawasan ini, kesadaran akan

33 Baharuddin, Manajemen Pendiikan Islam, (UIN Maliki Press, Malang. 2010), 91.

34 George R Terry, Prinsip-Prinsip Manajemen, Alih bahasa oleh J. Smith. D.F.M (Jakarta: Bumi Aksara,2009), 17. 
prestasi dan mutu madrasah yang menjadi penekanan utama sehingga masyarakat terlibat membimbing, mengawasi serta mendorong masyarakat lainnya untuk terlibat di dalamnya.

Upaya peningkatan mutu pendidikan madrasah dengan peranserta masyarakat dimaksudkan sebagai usaha dan langkah-langkah untuk meningkatkan kecerdasan dan kesejahteraan seluruh masyarakat khususnya masyarakat di sekitar madrasah. Bersamaan dengan hal tersebut, keterlibatan atau partisipasi masyarakat perlu terus didorong dan ditingkatkan, agar madrasah yang sudah dibangun dengan perjuangan dapat melaksanakan peran dan fungsinya sebagai lembaga pendidikan Islam yang memadai.

Muhaimin menjelaskan bahwa sebenarnya pendidikan Madrasah diharapkan dapat memenuhi tiga kepentingan utama, yaitu (1) sebagai wahana untuk memperdalam ilmu-ilmu ke-Islaman; (2) memperjelas dan memperkokoh keberadaan madrasah agar dapat memenuhi standar nasonal pendidikan; dan (3) mampu merespon tuntutan-tuntutan masa depan, dalam arti sanggup melahirkan manusia memiliki kesiapan memasuki era globalisasi maupun era reformasi. Penjelasan di atas, memberikan makna yang sangat gambelang, bahwa kemampuan merespon tuntutan masa depan, adalah ikhtiar penting dari penyelenggaraan pendidikan Islam. Cakrawala pendidikan Islam yang berorientasi global, tentuntanya disemangati sebagai jalan merebut kembali masa keemasan ilmu pengetahuan Islam, yang unggul secara ilmu pengatahuan, dan mewujudkan kesejahtraan dalam tatanan masyarakat yang sejahtera secara lahir bathin. ${ }^{35}$

Berdasarkan uraian tersebut, partisipasi masyarakat memiliki peran dalam menentukan laju dan eksisnya madrasah guna meningkatkan kualitas pendidikan di dalamnya. Pembangunan madrasah akan tetap berjalan dengan hasil yang baik jika masyarakat tetap dan istiqomah bersedia ikut ambil bagian atau mau berpartisipasi dalam tiap tahap perencanaan, pelaksanaan, dan pengawasan program-program madrasah.

\section{Hambatan Masyarakat dalam Berpartisipasi Untuk Meningkatkan Mutu}

\section{Pendidikan di Madrasah Ibtidaiyah Islahul Muta'allim Pagutan Kota Mataram.}

Berdasarkan temuan penelitian bahwa masyarakat mengahadapi hambatanhambatan yang berpartisipasi untuk meningkatkan mutu pendidikan madrasah, yaitu hambatan berupa kesibukan masyarakat dalam bekerja, kurangnya informasi tentang

${ }^{35}$ Muhaimin, Pemikiran dan Aktualisasi Pengembangan Pendidikan Islam.(Jakarta :PT Raja Grapindo Persada, 2011). 
program madrasah, dan kurangnya pengetahuan sebagian masyarakat tentang arti pentingnya pendidikan bagi anak.

Dengan bergulirnya regulasi tentang desentralisasi pendidikan, lembaga pendidikan Islam (Madrasah) harus lebih memacu diri dalam rangka pengembangan, melakukan reorientasi pendidikannya, karena lembaga pendidikan diberikan keleluasaan untuk mengatur dirinya. Madrasah harus dibuat lebih relevan dengan lingkungan siswa dan pengembangan kurikulum harus sesuai dengan keadaan daerah dan wilayah. Tujuannya agar madrasah tidak terisolasi dengan masyarakat dan madrasah harus berorientasi kepada kenyataan kehidupan dan masalah masyarakat. Karena itu hubungan antar madrasah dengan masyarakat yang baik harus menjadi perhatian terus menerus dari setiap kepala madrasah dan stafnya.

Peningkatan mutu pendidikan madrasah menjadi semakin penting bagi institusi yang digunakan untuk memperoleh kontrol yang lebih baik melalui usahanya sendiri dan dukungan masyarakat. Institusi/lembaga pendidikan harus mendemonstrasikan bahwa mereka mampu memberikan pendidikan yang bermutu kepada peserta didik. Penentuan label/predikat bermutu dari suatu institusi salah satunya dapat ditentukan oleh konsumen (pengguna lulusan).

Dalam konteks Madrasah, Muhaimin ${ }^{36}$ berpendapat bahwa tantangan yang dihadapi oleh madrasah terdiri dari faktor internal dan eksternal. Faktor internal menyangkut:

1. Mutu; penyelenggaraan dan pengelolaan madrasah umumnya belum dapat melahirkan lulusan yang berkualitas.

2. Pendidik; sebagian besar tenaga pendidik dan kependidikan di madrasah belum berkualifikasi sesuai dengan tuntutan perundang-undangan.

3. Kurikulum; sebagian besar madrasah belum dapat mengimplementasikan standar isi dan belum sepenuhnya dapat mencapai standar kompetensi lulusan minimal. Persentase lulus ujian nasional cukup menggembirakan, kurang lebih $92 \%$, tetapi perolehan nilai rata-rata masih rendah.

4. Manajemen; penyelenggaraan dan pengelolaan madrasah umumnya belum dikelola dengan manajemen yang profesional.

5. Sarana prasarana; belum memadainya sarana dan prasarana pada sebagian besar madrasah.

36 Muhaimin, Manajemen Pendidikan; Aplikasinya dalam Penyusunan Rencana Pengembangan Sekolah/Madrasah, (Jakarta: Prenada Media group, 2010), 208. 
Secara ekternal, tantangan yang dihadapi madrasah secara khusus adalah menyangkut persepsi masyarakat dan pemerintah yang cenderung diskriminatif, sehingga madrasah kurang mendapatkan perhatian, termasuk dalam penyediaan anggaran, bahkan ada yang menganggap sebagai lembaga pendidikan kelas dua setelah sekolah.

Melihat hambatan yang dihadapi masyarakat dalam turuserta berpartisipasi tersebut harus disikapi secara serius oleh madrasah, madrasah harus mencari alternatif solusi pemecahan masalah yang dihadapi oleh masyarakat. Karena madrasah sangat berkepentingan dengan dukungan dan partisipasi masyarakat. Madrasah harus mampu melakukan manajemen pengelolaan yang baik, dan dikelola dengan manajemen yang profesional. Dengan demikian, madrasah akan dapat memanfaatkan berbagai sumberdaya yang terdapat dalam masyarakat untuk kepentingan peningkatan mutu pendidikan di madrasah.

Menurut Baharuddin, walaupun secara sistemik pendidikan Islam merupakan sub sistem pendidikan nasional, tetapi sesungguhnya pendidikan Islam memegang peranan penting dan strategis dalam pencapaian tujuan pendidikan nasional. Namun, karena menjadi sub sistem itu pula, maka pemberdayaan lembaga-lembaga pendidikan Islam di era otonomi pendidikan, masih mengalami banyak hambatan, baik hambatan psikologis, birokratis, maupun sosiologis. ${ }^{37}$

Disamping itu, Baharuddin menyatakan bahwa tantangan yang dihadapi madrasah sebagai lembaga pendidikan Islam terletak pada pergolakan dan disparitas paradigma, membekunya kreativitas guru, politisasi kewenangan dan mandulnya dukungan masyarakat.

Dalam pergolakan dan disparitas paradigma, arah pengembangan lembaga pendidikan islam terlihat lebih ditekankan pada usaha pemahaman, pembentukan watak dan prilaku peserta didik agar sesuai dengan ajaran agama Islam. Ini terlihat dari mata pelajaran agama Islam yang menjadi prioritas dalam seluruh aspek pembelajaran lembaga pendidikan Islam. Akan tetapi, dengan selalu tanggap terhadap perubahan-perubahan situasi dan kondisi, maka pelajaran agama di lembaga pendidikan Islam seharusnya dikaitkan dengan persoalan-persoalan riil yang dihadapi masyarakat. ${ }^{38}$

Sedangkan aspek dukungaan masyarakat, gambaran dukungan masyarakat terhadap keberadaan lembaga pendidikan Islam sebenarnya menyimpan potensi begitu besar

\footnotetext{
${ }^{37}$ Baharuddin \&.Moh. Makin, Manajemen Pendidikan Islam,Transformasi Menuju Sekolab/Madrasah Unggul.(Malang: UIN-MALIKI PRESS.2010), 16.

${ }^{38}$ Baharuddin, Pengembangan Lembaga Pendidikan Islam Menuju Pengelolaan Profesional dan Kompetitif ( Malang : UIN Maliki Press, 2011), 25.
} 
terutama wali murid. Namun demikian walaupun dukungan masyarakat terjalin begitu kuat, tentunya masih ada beberapa problem yang menjadi kendala, menurut Baharuddin ${ }^{39}$ yaitu: (1) Masih rendahnya penghasilan orang tua siswa lembaga pendidikan Islam yang kebanyakan mata pencahariannya adalah petani penggarap, buruh tani, dan pedagang. (2) Kurangnya dukungan dan kepedulian masyarakat terhadap kegiatan lembaga pendidikan islam. (3) kerjasama dengan instansi lain dalam meningkatkan kualitas belum optimal.

Oleh karena itu, lembaga pendidikan Islam dalam hal ini madrasah perlu menghadirkan suatu konstruksi dan formula yang dapat mengakomudir kebutuhan masyarakat, bukan saja pada tataran pengetahuan agama melainkan juga keterampilan atau skill bagi peserta didik dalam menghadapi peradaban modern. Perbaikan sistem secara internal dan eksternal harus terus diupayakan oleh para pengelola pendidikan Islam di madrasah, agar eksistensi pendidikan di madrasah mendapatkan posisi di kalangan masyarakat dan tidak dimarginalkan secara kualitas.

Mengacu pada penjelasan-penjelasan di atas, maka penyelenggaraan pendidikan Islam, dalam praktiknya dapat dilaksanakan pada jalur pendidikan formal, nonformal dan informal. Oleh sebab itu, penyelenggaraan pendidikan Islam menjadi tanggung jawab pemerintah, orang tua dan masyarakat. Dalam konteks penyelenggaraan pendidikan Islam di Indonesia, penyelenggaraan pendidikan Islam melalui jalur formal, sangat lebih memungkinkan untuk dilakukan pengembangan demi pengembangan, secara terprogram dan terus menerus, mengingat keberadaan keberadaan lembaga-lembaga pendidikan Islam tersebut sudah melembaga, terprogram, teratur dan dalam sistem yang terkontrol.

Partisipasi masyarakat dalam pendidikan merupakan bukti bahwa negara bukan satu-satunya penyelenggara pendidikan. Desentralisasi dan otonomi pendidikan merupakan tuntutan mendesak yang harus segera ditanggapi. Desentralisasi pendidikan merupakan upaya untuk mendelegasikan wewenang di bidang pendidikan yang seharusnya dilakukan oleh pemerintah kepada masyarakat. Sehingga partisipasi masyarakat merupakan kebutuhan mutlak dalam menentukan masa depan pendidikan saat ini. Dalam iklim desentralisasi, budaya instruksi dan komunikasi satu arah sudah tidak tepat bahkan dapat menghambat potensi kritis yang ada dalam masyarakat.

${ }^{39}$ Baharuddin, Pengembangan Lembaga Pendidikan, 52. 


\section{Simpulan}

Berdasarkan hasil penelitian dan pembahasan yang telah dipaparkan pada bab sebelumnya, peneliti dapat menarik beberapa kesimpulan sebagai berikut:

1. Bentuk partisipasi masyarakat dalam upaya meningkatkan mutu pendidikan di madrasah Ibtidaiyah Islahul Muta'allim lingkungan Karang Genteng Pagutan dikelompokkan menjadi tiga bagian, yaitu 1) partisipasi pada input pembelajaran berupa keterlibatan masyarakat dalam hal penerimaan siswa baru dan sumber daya lainnya seperti peralatan dan finansial. 2) Proses, yaitu berupa keterlibatan masyarakat dalam membina para siswa baik di madrasah maupun di luar madrasah, dan 3) Output, yaitu keterlibatan masyarakat dalam menyiapkan siswa yang memiliki akhlakul karimah dan skill.

2. Peran partisipasi masyarakat dalam meningkatkan muru pendidikan di Madrasah Ibtidaiyah Islahul Muta'allim Pagutan Mataram dibagi ke dalam peran perencana dan pengawas. Masyarakat terlibat dalam merencanakan program madrasah, terutama program strategis madrasah. Disamping itu masyarakat juga terlibat dalam peran pengawasan terhadap program madrasah dan capaian madrasah terhadap program yang sudah disusun.

3. Hambatan yang dihadapi masyarakat dalam berpartisipasi untuk meningkatkan mutu pendidikan di Madrasah Ibtidaiyah Islahul Muta'allim Pagutan Mataram adalah masalah kesibukan dalam bekerja, kurangnya informasi tentang programprogram madrasah, dan masih minimnya pengetahuan sebagian besar masyarakat tentang pentingnya arti partisipasi dalam upaya meningkatkan mutu pendidikan anak.

\section{Implikasi Teoritik}

Pengembangan sumber daya manusia (SDM), pemerintah telah mengambil kebijakan-kebijakan strategis, yaitu pembangunan pada bidang pendidikan. Mengingat, maju mundurnya atau berkualitas tidaknya sumber daya manusia sangat tergantung dari kualitas pelaksanaan pendidikan sebagai agen dan pencetak insane-insan berpendidikan.

Temuan penelitian ini adalah masyarakat di sekitar Madrasah Ibtidaiyah Islahul Muta'allim pagutan Mataram memiliki kepedulian terhadap eksistensi madrasah, kepedulian mereka itu bersifat moril dan materil meskipun mereka masih belum terlibat secara utuh dalam berbagai program madrasah. 
Temuan penelitian ini mempertajam makna partisipasi Keith Davis, bahwa partisipasi sebagai keterlibatan pikiran dan perasaan masyarakat di dalam situasi kelompok yang mendorongnya untuk memberikan sumbangan kepada kelompok dalam usaha mencapai tujuan serta tanggung jawab terhadap usaha mencapai tujuan yang bersangkutan.

Partisipasi sebagai syarat penting bagi peningkatan mutu pendidikan madrasah. Partisipasi menuntut adanya pemahaman yang sama dari pihak madrasah dan masyarakat (orangtua) terhadap visi, misi, dan tujuan pendidikan di madrasah. Partisipasi tidak cukup hanya dipahami oleh madrasah sebagai bagian yang penting bagi keberhasilan peningkatan mutu pendidikan, akan tetapi masyarakat juga harus memahami dan diberikan porsi yang memadai dalam turutserta berpartisipasi dalam membangun pendidikan di madrasah.

Partisipasi masyarakat juga diartikan sebagai keterlibatan kelompok masyarakat dalam membuat keputusan strategis madrasah. Untuk itu, kepala madrasah bersama guruguru serta warga madrasah lainnya harus dapat bekerja secara transparan dan bertanggungjawab dalam mengemban visi, misi dan program madrasah yang diamanatkan oleh masyarakat.

\section{DAFTAR RUJUKAN}

Andi Prastowo. 2011, Memahami Metode-metode Penelitian, Jogjakarta : Ar Ruzz Media.

Arikunto, Suharsimi. 1998, Prosedur Penelitian, Suatu Pendekatan Praktek, Jakarta : PT. Rineka Cipta.

Baharuddin. 2010, Manajemen Pendidikan Islam. UIN-MALIKI Press: Malang.

Baharuddin. 2011, Pengembangan Lembaga Pendidikan Islam Menuju Pengelolaan Profesional dan Kompetitif, Malang : UIN Maliki Press.

Departemen Pendidikan Dan Kebudayaan. 2001, Kamus Besar Bahasa Indonesia, edisi Ketiga, Jakarta : Balai Pustaka.

Dwiningrum, Siti irene Astuti. (2011), Desentralisasi dan Partisipasi Masyarakat dalam Pendidikan. Pustaka Pelajar: Yogyakarta.

Edward Sallis. 2010, Total Quality Management In Education, Ircisode, Yogyakarta.

George R Terry, 2009, Prinsip-Prinsip Manajemen, Alih bahasa oleh J. Smith. D.F.M. Jakarta: Bumi Aksara.

John M. Echols dan Hassan Sadilly, 2000, Kamus Inggris Indonesia, Jakarta: Gramedia Moleong, Lexi.J. 2000, Metodologi Penelitian Kualitatif, Bandung : PT. Remaja Rosdakarya. 
Moleong, Lexi.J. 2011, Metodologi Penelitian Kualitatif, Edisi revisi „Bandung : PT. Remaja Rosdakarya.

Muhaimin. 2001, Paradigma Pendidikan Islam; Upaya Mengefektifkean Pendidikan Agama Islam di Sekolah, Bandung: Remaja Rosda Karya.

Muhaimin. 2002, Reorientasi Pengembangan Guru, Mudjia Rahardjo (Ed), Quo Vadis Pendidikan Islam; Pembacaan Realitas Pendidikan Islam, Sosial dan Pengetabuan, Malang: Cindekia Paramulya.

Muhaimin. 2010. Manajemen Pendidikan; Aplikasinya dalam Penyusunan Rencana Pengembangan Sekolah/Madrasah, Jakarta: Prenada Media group.

Mulyono. (2009), Manajemen Administrasi dan Organisasi Pendidikan. Ar-Ruzz Media: Yogyakarta.

Nasution, Zulkarnain. (2010), Manajemen HUMAS di Lembaga Pendidikan; Konsep, Fenomena dan Aplikasinya. UMM Press: Malang.

Noeng Muhadjir. 2000, Metodologi Penelitian Kualitatif (Edisi IV), Yogyakarta : Rake Sarasin.

Pidarta, Made. (2004), Manajemen pendidikan Indonesia. PT. Rinela Cipta: Jakarta.

Sagala, Syaiful. (2010), Manajemen Strategik dalam peningkatan Mutu Pendidikan. Al-Fabeta: Bandung.

Sallis, Edward. (2010), Total Quality Management In Education. Yogyakarta: Ircisode.

Sanapiah Faisal. 1998, Pelatihan Metode Penelitian Kualitatif, Surabaya : Badan Musyawarah Perguruan Tinggi Swasta Indonesia (BMPTSI) Wilayah VII Jawa Timur.

Sugiyono. 2007, Metode Penelitian Kuantitatif, Kualitatif dan R\&D, Bandung: AlFabeta.

Syamsuddin AR. 2011, Metode Penelitian Pendidikan Babasa, Bandung: Diterbitkan atas Kerjasama Program Pascasarjana Universitas Pendidikan Indonesia (UPI) dengan PT. Remaja Rosdakarya.

Tim Penyusun. (2008), Kumpulan Ayat dan Hadits Tentang Pendidikan. Jurusan Tarbiyah, STAIN Pamekasan: Madura. 